\title{
Carcass yield and intestinal morphology of male rabbits fed diets supplemented with turmeric (Curcuma Longa) powder
}

\author{
E.O. OKANLAWON*, K.O. BELlO, O.S. AKINOLA, O.O. OLUWATOSIN, O.T. \\ IREKHORE \& R.O. ADEMOLUE \\ (E.O.O, K.O.B, O.S.A, O.O.O \& O.T.I.: College of Animal Science and Livestock Production, \\ Federal University of Agriculture Abeokuta; R.O.A.: College of Animal Production and \\ Technology, Obafemi Awolowo University Ile Ife) \\ *Corresponding author's email: edenokanlawon@gmail.com
}

\begin{abstract}
Thirty-two (7-8 weeks old) male rabbits that weighed between 700 and $800 \mathrm{~g}$ were used to determine the effect of inclusion of Turmeric powder on carcass yield and intestinal morphology of rabbits. The rabbits were randomly allotted to four diets containing varying levels of turmeric powder $(0,5,10$ and $15 \mathrm{~g})$ in a complete randomized design. Data were collected on carcass yield, duodenum, jejunum, ileum, crypt depth, mucosal thickness and analyzed using ANOVA. Significant $(\mathrm{p}<0.05)$ differences were obtained on bled and eviscerated weights, forelimbs, hind limbs, neck, tail and loin. Highest $(\mathrm{p}<0.05)$ duodenum crypt depth $(111.50 \mu \mathrm{m})$ was obtained with buck fed diet containing $15 \mathrm{~g}$ turmeric inclusion while buck fed with diet containing $0 \mathrm{~g}$ turmeric had the least value of $(67.67 \mu \mathrm{m})$. This was similar $(\mathrm{p}>0.05)$ with values obtained for buck fed diets containing $5 \mathrm{~g}$ turmeric $(73.83 \mu \mathrm{m})$ and those fed with $10 \mathrm{~g}$ turmeric inclusion $(79.33 \mu \mathrm{m})$. There was significant difference $(\mathrm{P}<0.05)$ of rabbit fed with diets with turmeric on jejunum villi height. There was significant difference $(\mathrm{P}<0.05)$ in jejunum crypt depth and mucosal thickness. However, $10 \mathrm{~g}$ inclusion could be assumed as economic inclusion level for carcass yield and intestinal increase in rabbit production.
\end{abstract}

Keywords: rabbit; turmeric; Carcass; internal organ; intestinal morphology Original scientific paper. Received 4 May 2020; revised 20 Nov 2020.

\section{Introduction}

Rabbit is a very good source of protein with balanced amino acid profile (Oladunjoye et al., 2006). Its meat is appreciated for its organoleptic properties in particular through its high crude protein/energy ratio, high essential fatty acids content and low cholesterol rate (Gondret \& Bonneau, 1998; Esminger, 1991; Nistor et al., 2013).

The meat is thus recommended for people living with heart disease and diabetes.
Nistor et al. (2013) reported that rabbit meat is richer in calcium $(21.4 \mathrm{mg} / 100 \mathrm{~g})$ and phosphorus $(347 \mathrm{mg} / 100 \mathrm{~g})$ than other types of meat and lower in fat $(9.2 \mathrm{~g} / 100 \mathrm{~g})$ and cholesterol (56.4). The meat can be evaluated for its carcass quality as to other livestock and this has to satisfy economic objectives such as saleable meat yield and attractiveness to consumer (Dalle Zote, 2002). The dressing percentage is an important economic variable in the rabbit market. Some combinations of

Ghana Jnl Agric. Sci. 55 (2), 97 - 106

GJAS is an Open Access Journal and distributed under the terms of the Creative Commons (CC) License [CC BY 4.0] 
measurements such as retail cut weight or length measurement are necessary to predict lean percentage in the carcass (Dalle Zote, 2002). Information on carcass characteristics is therefore helpful for the effective utilization of rabbit meat. However, meat composition has been reported to influence by all management practices (Laura et al., 2019).

Small intestinal helps in digestion and absorption of nutrients in rabbits which are similar to other livestock. Bicarbonate ions are secreted in the duodenum to neutralize the acidity of the chyme passing from the stomach. Most of the digestion of carbohydrates and simple proteins takes place in the duodenum and jejunum and the products of this digestion (monosaccharides, amino acids) are absorbed across the jejunal brush border (Rees-Davies \& Rees-Davies, 2003). This includes digestion and absorption of the caecotroph material such as amino acids, volatile fatty acids, vitamins, and digested microbial organisms. The digestion of caecotroph microbial protein is aided by the addition of lysozyme into the caecotrophs as they pass through the large intestine (Camara, 1984). Lysis of the microbes within the caecotrophs also releases microbial enzymes, notably amylase, which enhances the rabbit's digestive processes. The ileum also plays an important role in regulating and recycling the electrolytes secreted by the stomach and proximal small intestine by reabsorbing bicarbonate ions (Rees-Davies \& Rees-Davies, 2003). However, it has been proven that the increase in the size of the small intestine will help to increase the bodyweight gain of an animal.

Phytobiotics are relatively new class of feed additives and in recent years these feed additives have gained considerable attention as Natural Growth Promoters
(NGPs) and have been identified as effective alternatives to antibiotics (Panda et al., 2009) in the poultry industry. This may be probably due to the ban of most antibiotics usage in poultry and rabbit. The phytobiotics include turmeric, ginger, garlic that has wide array of health benefits at low cost and no adverse effects (Soni et al., 1997). Phytobiotics as NGPs are highly developed as feed additives to improve immunity, growth performance and effective in improving the health of the digestive tract (Panda et al., 2009) and are effective antimicrobial in animals (Panda et al., 2006). Feeding diets containing phytobiotics may result in the inhibition of the growth and colonization of entropathogenic microbes in the digestive tract, thus contributing to the balance of gut microflora and ecology (Harris et al., 2001).

Turmeric (Curcuma longa) is a perennial herb and a member of the ginger family, Zingaberaceae. The rhizome is the most important portion of the plant, which can be used as spice and also for medicinal purposes in the treatment of many diseases (Nita, 2003). Curcuminoids are the active ingredients of turmeric, which includes mainly curcumin (diferuloyl methane). Curcumin has several pharmacological effects including antifungal (Wuthi-udomier et al., 2000), immunomodulatory (Anthony et al.,1999), anti-oxidative (Osawa et al., 1995) and antimutagenic (Soni et al., 1997). In vitro, curcumin exhibits anti-parasitic, antispasmodic, anti-inflammatory and gastrointestinal effects; and also inhibits carcinogenesis and cancer growth. In vivo, there are experiments showing the anti-parasitic, anti-inflammatory potency of curcumin and extracts of C.longa. (Araújo \& Leon, 2001) reported that curcumin reduces the activities of reactive oxygen species and elevate 
the antioxidant enzyme; superoxide dismutase, catalase and glutathione peroxidase levels in the blood (Joe \& Lokesh, 1994). Studies also show that turmeric extract works effectively for the treatment of osteoarthritis of the knee and also as a weak phytoestrogen and therefore seems to have cancer-protective effect (Soni et al., 1997). Laboratory studies also reveal that curcumin induces programmed cell death of colon cancer cells and it also suppresses micro-inflammation in the gastrointestinal tract associated with inflammatory bowel diseases (Nita, 2003). These properties are due to the intrinsic anti-oxidative abilities of Curcumin (Okamoto et al., 2002).

Due to some vitamins and minerals that turmeric contains and the economic and nutritional demands of our modern society for food from micro livestock necessitate the raising of rabbit under intensive production system. Under such circumstances, antimicrobial feed additives such as antibiotics are often used to suppress or eliminate harmful microorganisms in the intestine and to improve growth and feed efficiency. However, one major aspect of food production and safety today is the reduction in the use of antibiotics and other medicinal products in livestock production largely due to fears over bacterial resistance and possible transmission of these antibiotic residues into the human food chain. Research has been carried out on turmeric to check the effect on growth performance at $0.5 \%$ and $1.0 \%$ inclusion in poultry and $5 \%$ inclusion level in rabbit (Al-kassie et al., 2001; Kuman et al., 2001; Durrani et al., 2006); biochemical profile, meat characteristics and as antioxidant (Greenwald, 2004), anti-inflammatory and hypocholesterolemic agents (Chattopadhyay et al., 2004).

Turmeric has been used as dietary supplementation on voluntary feed intake, nutrient digestibility and growth both in rabbits and poultry (Osawa et al., 1995). However, there is dearth of information on the effect of turmeric on carcass yield and intestinal morphology and this, therefore, necessitated the present study.

\section{Materials and Methods}

The study was conducted at the Rabbit unit of Federal College of Agriculture Farm, Institute of Agriculture Research and Training (IAR\&T) Ibadan, Oyo State, Nigeria. The turmeric rhizome was purchased from the open market.

The rhizome was washed with water before cutting in order to increase the surface area and boiled for 30-45 minutes in a water bath at $60^{\circ} \mathrm{C}$ to soften the turmeric and make grinding easy and also enhance its colour and flavour. Thereafter the boiled turmeric was air-dried for 10 days and milled into fine powdery according to the method described by Jayaprakasha et al. (2005) and stored in airtight container until use.

A total of 32 (7-8 weeks old) male (buck) rabbits with weight range of 700-800 $\mathrm{g}$ weaner rabbits were used for the study. The animals were purchased from a reputable farm. They were weighed and acclimatize for two weeks before they were allotted into four dietary treatments in a complete randomize design arrangement at four levels $(0,5 \mathrm{~g}, 10$ $\mathrm{g}, 15 \mathrm{~g}$ ) of turmeric inclusion. Each treatment having eight replicates. Before stocking, the pen (house) was cleaned thoroughly and disinfected. The animals were fed with a grower diet containing 16\% Crude Protein (CP) and $2450 \mathrm{kcal} / \mathrm{kg}$ Metabolizable Energy (ME). Feed and water were supplied ad libitum daily. All other routine management practices were observed. They were fed with the experimental diets for 70 days. On day 71 , four animals per 
dietary treatment were fasted for 24 hours and sacrificed for carcass, internal organ and intestinal morphology analysis. Data on carcass were collected on (live weight, body weight, eviscerated weight, dressing percentage, cuts parts and organs and expressed as percentage of live weights.

Rabbits were weighed individually at the beginning of the experiment and subsequently on weekly basis. The offals of each carcass were used for intestinal morphology. Each small intestine was sectioned into three parts of duodenum, jejunum and ileum. All samples were approximately $1-\mathrm{mm}$ thick. The longitudinal sections (hemicylindrical and longitudinal) were $15-\mathrm{mm}$ long. Samples were dehydrated in graded concentrations of alcohol, cleared in xylene, and embedded in paraffin. Samples were then cut into $4-\mu \mathrm{m}$ thick sections and stained with hematoxylin-eosin in a procedure described by Eyarefe et al. (2008). Intestinal morphology data were collected on thickness, crypt depth and mucosal of duodenum, jejunum and ileum.

All data collected were analysed using ANOVA as contained in SAS (2000). Significant means were separated using Duncan Multiple Range Test as contained in SAS (2002).

\section{Results and Discussion}

Table 1 shows the effect of turmeric on carcass yield. Carcass characteristics evaluated were significantly $(p<0.05)$ influenced by the inclusion of turmeric. The highest dressing percentage recorded with animals fed $10 \mathrm{~g}$ and $15 \mathrm{~g}$ could be attributed to better utilization of dietary treatment at these levels as revealed by their higher life-weight and eviscerated weight. This finding agrees with the report of Raghdad and Al-Kassie (2012) that stated that supplementation of turmeric powder in broiler chicken significantly increased the dressing percentage as level of inclusion increased. The results of cut-off parts and organs obtained did not follow a definite pattern that can be attributed to turmeric powder inclusion and it supports the report of Onu (2010) who stated that the addition of turmeric did not affect the development of certain body organs. The observed variations in viscera weight in this study were greater than the weight previously reported by Pascual and Pla (2007) and this might be because the researchers studied younger rabbits and it has also been reported that age affects the development of specific tissues and organs (Ouhayoun, 1998). Turmeric powder causes a decrease in weight of some internal organs such as the heart and liver of rabbits as the level of inclusion increases to $15 \mathrm{~g}$ and this could be attributed to high concentration of turmeric in the experimental diet. This result was in close agreement with the results of Lal et al. (1999) and Al-Sultan (2003), who also concluded that feeding of high level of turmeric beyond $10 \mathrm{~g}$ alters the size of some major organs that are involved in nutrient metabolism. Ahmadi (2010) observed an increase in liver weight at 0.3 and $0.6 \mathrm{~g} / \mathrm{kg}$ with a decrease in size above $0.6 \mathrm{~g} / \mathrm{kg}$ and attributed it to favourable effects of turmeric powder inclusion on the liver relative weight of aflatoxin treated chickens. The author reported that addition of turmeric powder to this level significantly ameliorated the increase in the relative weight of liver observed in birds fed aflatoxin alone. In the study of Emadi and Kermanshahi (2007), 5 $\mathrm{g} / \mathrm{kg}$ turmeric powder showed the highest activity of lactate dehydrogenase (LDH) at 21 days of age and significantly decreased serum alkaline phosphatase (ALP) of the chickens 
and concluded that turmeric might have some positive effects on liver enzymes that directly or indirectly reflect a healthier liver status in broiler chickens.

Table 2 shows the effect of turmeric inclusion on intestinal morphology of male rabbits. Turmeric inclusion had significant $(\mathrm{p}<0.05)$ effects on duodenum crypt depth, jejunum villi height, jejunum crypt depth and jejunum mucosal thickness. However, there was no significant ( $>0.05)$ influence of turmeric on duodenum villi height, duodenum mucosal thickness, ileum villi height, ileum crypt depth and ileum mucosal thickness of male rabbit.

Highest $(\mathrm{p}<0.05)$ duodenum crypt depth $(111.50 \mu \mathrm{m})$ was obtained with buck fed diet that contained $15 \mathrm{~g}$ turmeric inclusion while buck fed with diet containing $0 \mathrm{~g}$ turmeric inclusion had the least value of (67.67 $\mu \mathrm{m})$. This was similar $(\mathrm{p}>0.05)$ with the values obtained for the buck fed diets containing 0.5 g turmeric inclusion $(73.83 \mu \mathrm{m})$ and those fed with $10 \mathrm{~g}$ turmeric inclusion $(79.33 \mu \mathrm{m})$. The result obtained shows that there was an increase in the duodenum villi height, duodenum crypt depth and mucosal thickness. This study shows that bodyweight is directly related to duodenum weight which aids digestion and absorption of nutrients. This opinion is in line with the report of Miles et al. (2006) who reported that increased villi height is an indicator of an increase in digestion and absorption of nutrients. Sieo et al. (2005) also reported that an increased intestinal villi height and the ratio of villi height to crypt depth is an indication of the vast area for nutrient absorption and higher absorption function.

The increase in the absorptive surface in this study was in line with the findings of (Paul et al., 2007; Viola \& Vieira 2007; Senkoylu et al., 2007). Rajput et al. (2013) reported that dietary supplementation of $0.2 \mathrm{~g} / \mathrm{kg}$ pure curcumin derived from turmeric in a cornsoybean-based diet increased the villus height and width of duodenum of broiler.

There was significant difference $(\mathrm{P}<0.05)$ in male rabbit fed with diets supplemented with turmeric inclusion on jejunum villi height. The highest jejunum villi height $(338.50 \mu \mathrm{m})$ was recorded with buck fed diets containing $0 \mathrm{~g}$ turmeric inclusion and least (136.67 $\mu \mathrm{m})$ with those on $10 \mathrm{~g}$ turmeric inclusion. Jejunum crypt depth was significant $(\mathrm{P}<0.5)$ with varying levels of turmeric inclusion. The highest jejunum crypt depth value $(110.00 \mu \mathrm{m})$ was recorded among rabbits on $0 \mathrm{~g}$ turmeric inclusion while the lowest $(56.50 \mu \mathrm{m})$ at 5 g. There was significant difference $(\mathrm{P}<0.05)$ in jejunum mucosal thickness. The highest jejunum mucosal thickness $(448.33 \mu \mathrm{m})$ was recorded at $0 \mathrm{~g}$ turmeric inclusion and least $(215.50 \mu \mathrm{m})$ at $10 \mathrm{~g}$ turmeric inclusion of rabbit.

This result is not in line with the report of Rajput et al. (2013) who reported that dietary supplementation of $0.2 \mathrm{~g} / \mathrm{kg}$ pure curcumin derived from turmeric in a cornsoybean based diet increased the villus height and width of jejunum and Nilay and Sabire (2014) who reported effects of different doses of probiotic yeast Saccharomyces cerevisiae on the duodenal mucosal in rabbits.

No significant $(p>0.05)$ effect of turmeric on ileum villi height, ileum crypt depth and ileum mucosal thickness, but there was an increase in the values observed, which is an indication of an increase in digestion and absorption of nutrients which is in line with the report of Miles et al. (2006) and (Sieo et al., 2005). 
Also, the result was in line with the report of Rajput et al. (2013) reported that dietary supplementation of $0.2 \mathrm{~g} / \mathrm{kg}$ pure curcumin derived from turmeric in a corn-soybean based diet increased the villus height and width ileum of broiler.

\section{Conclusion}

It could be concluded from the results obtained from this study that turmeric had no detrimental effect on carcass yield and intestinal morphology of rabbits. However, 10 $\mathrm{g}$ inclusion could be assumed for better carcass yield and intestinal increase in the rabbit production enterprise.

\section{REFERENCES}

Aduku, A.O. \& Olukosi, J.O. (1990) Rabbit management in the tropics: Production, utilization, marketing, economics, practical training, research and future prospects. Living Book Series, Abuja, Nigeria; ISBN 978- 2022-11-X.

Ahmadi, F. (2010) Effect of turmeric (Curcuma longa) powder on performance, oxidative stress

state and some of blood parameters in broiler fed on diets containing aflatoxin Bl. Globe Veterinary 5, $312-317$.

Al-Kassie, G.A.M., Mohssen, A.M. \& Abd-Al-Jaleel, R.A. (2001) Modification of performance and physiological aspects of broilers on the addition of a mixture of curcumin and turmeric to the diet. Research Opinion in Animal and Veterinary Science 1, 31 - 34 .

AL-Sultan, S. I. (2003) The Effect of Curcuma longa (Turmeric) on Overall Performance of Broiler Chickens. International Journal of Poultry Science 2 (5), 351 - 353.

Anthony, S., Kuttan, R. \& Kuttan, G. (1999) Immunomodulatory activity of curcumin. Immunological lvestigation. A Journal of Molecular and Cellular Immunology 28, 291 -303 .
Araújo, C.A.C. \& Leon, L.L. (2001) Biological Activities of Curcuma longa L. Mem Inst Oswaldo Cruz, Rio de Janeiro 96 (5), 723 728.

Camara, V. M. \& Prieur, D. J. (1984) Secretion of colonic isoenzyme of lysozyme inassociation with caecotrophy of rabbits. Animal Journal of Physiology 247, 19 - 23.

Chattopadhyay, I., Biswas, K., Bandyopadhyay, U. \& Banerjee, R.K. (2004) Turmeric and curcumin: Biological actions and medicinal applications. Current Science 87, 44 - 53.

Dalle Zotte, A. (2002) Perception of rabbit meat quality and major factors influencing the rabbit carcass and meat quality. Livestock Production Science 75, 11 - 32 .

Durrani, F.R., Mohammed I., Asal S., Shhail S.M., Naila C. \& Durrani, Z. (2006) Effect of different levels of feed added turmeric (Curcuma longa) on the performance of broiler chicks. Journal of Agricultural. and Biological Science 1, 9-11.

Emadi, M. \& Kermanshahi, H. (2006) Effect of turmeric rhizome powder on performance and carcass characteristics of broiler chickens. International Journal of Poultry Science 5, $1069-1072$.

Esminger, M.E. (1991) Animal Science, $9^{\text {th }}$ ed. Interstate Publisher Inc. Danville, U.S.A., $391-402$.

Eyarefe, O. D., Emikpe, B. O. \& Arowolo, F. O. (2008) Small bowel responses to enteral and glutamine administration following massive small bowel resection in rabbit. Africa Journal Medical Science 37, 309 - 314.

Gondret. F. \& Bonneau, M. (1998) Mise en place des caracteristiques du muscle chez le lepin et incidence sur la qualite de la viande, INRA Production, Animal 11 (5), 335 - 347. 
Greenwald, P. (2004) Clinical trials in cancer prevention: current results and perspectives for the future. The Journal of. Nutrition 134, $3507 \mathrm{~S}-3512 \mathrm{~S}$.

Harris, J.C., Cottrell, S., Plummer, S. \& Lioyd, D. (2001) Antimicrobial properties Allium sativum (garlic). Application of Microbiology and Biotechnology 57, $282-286$.

Jayaprakasha, K.G. \& Jaganmohan, R. (2005) Chemistry and biological activities of $\mathrm{C}$. longa. Trends Food Science. Technology 16, $533-546$.

Joe, B. \& Lokesh, B.R. (1994) Role of capsaium, curcuminand dietary n-3 fatty acids in lowering the generation of reactive oxygen species in rat peritoneal macrophages. Journal Biochemistry and Biophysics 1224, $255-263$.

Kuman, P., Gupta, M.K., Ranjan, R., Singh, K.K. \& Yadawa, R. (2001) Curcuma longa as feed additives in broiler birds and its pathophysiological effects. Indian Journal of Biology 45, 272 - 277.

Lal, B., Kapoor, A.K. \& Asthana, O.P. (1999) Efficiency of Curcumin in the management of chronic anterio- uveitis. Phytother Research 13 (4), $318-322$.

Laura, G., Sihem, D., Francesco, G., Alberto, B., Achille, S., Marco, B., Gerolamo, X. \& Angela, T. (2019) Quality and Consumer Acceptance of Meat from Rabbits Fed Diets in Which Soyabean Oil is Replace with Black Soldier Fly and Yellow Mealworm Fats. MDPI journal of animal science. Volume 9/ issue/10.3390/ani9090629.

Lebas, F., Coudert, P., Rouvier, R. \& de Rochambeau, H. (1986) The Rabbit Husbandry Health and Production. FAO Animal Production and Health Series No. 21. FAO of the United Nations, Italy, $21-48$.
Miles, R.D., Butcher, G.D., Henry, P.R. \& Little, R.C. (2006) Effect of antibiotic growth promoters on broiler performance, intestinal growth parameters and quantitative morphology. Poultry Science 85, 476 - 485.

Nilay, S. \& Sabire, P. (2014) Effect of different doses of probiotics yeast Saccharomyces cerevisiae on the duodenal mucosal in rabbits. Indian Journal of Animal Research 49, 602 - 606.

Nistor, E., Bampidis, V. A., Păcală, N., Pentea, M., Tozer, J. \& Prundeanu, H. (2013) Nutrient Content of Rabbit Meat as Compared to Chicken, Beef and Pork Meat, Journal Animal Production Advance 3 (4), 172 - 176.

Nita, C.W. (2003) Safety and Anti-Inflammatory Activity of Curcumin: A Component of Turmeric (Curcuma longa). The Journal of Alternative and Complementary Medicine 9 (1), $161-168$.

Oladunjoye, F.O., Adedeji, T.A. \& Ojebiyi, O.O. (2006) A guide to Rabbit production and management.Ola printers, Ogbomoso. $3-4$.

Onu, P.N. (2010) Biotechnology in Animal Husbandry. Institute for Animal Husbandry Zemun 26, $383-392$.

Okamoto, T., Yamagishi, S., Inagaki, Y., Amano, S., Koga, K. \& Abe, R. (2002) Angiogenesis induced by advanced glycation end products and its prevention by cerivastatin. FASEB Journal 16 (14), 28 - 30.

Osawa, T.Y. Sugiyama, M. Inayoshi \& Kawakisi, M. (1995) Anti-oxidative activity of tetrahydrocurcuminoids. Biotechnology Biochemistry 59, 160-161.

Ouhayoun, J. (1998) Influence of the diet on rabbit meat quality. In: The nutrition of the rabbit (Edit. De Blas, C., Wiseman, J.), CAB International, 177 - 195. 
Panda, A.S., Rao, R. \& Raju, M. (2006) Natural growths promoters have potential in feeding systems Feed Technology 10, 23 - 35.

Panda, A.S., Rao, R. \& Raju, M. (2009) Phytobiotic, a natural growth promoter. Poultry International.1011.

Pascual, M. \& Pla, M. (2007) Changes in carcass composition and meat quality when selecting rabbits for growth rate. Meat Science Journal $77,474-481$.

Paul, S.K., Halder, G., Mondal, M.K. \& Samanta, G. (2007) Effect of organic acid salt on the Performance and gut health of broiler chicken. Journal of Poultry Science 44, 389 - 395.

Raghdad, A. \& Al-kassie, A. (2012) Use of turmeric (Curcuma longa) on the performance and some physiological traits on the broiler diets. The Iraqi Journal of Veterinary Medicine $\mathbf{3 6}$ (1), $51-57$.

Rajput, N.N., Muhammah, R., Zhong, X. \&Wang, T. (2013) Effect of dietary supplementation of curcumin on growth performance, intestinalmorphology and nutrients utilization of broiler chicks. Journal of Poultry Science 50, $44-52$.

Rees-Davies, R. \& Rees-Davies, J. A. E. (2003) Rabbit gastrointestinal physiology. The Veterinary Clinics Exotic Animal Practice 6, $139-153$.
Senkoylu, N., Samli, H.E., Kanter, M. \& Agma, A. (2007) Influence of a combination offormic and propionic acids added to wheat- and barley-based diets on the performance and gut histomorphology of broiler chickens. Acta Veterinaria Hungarica 55, $479-490$.

Sieo, C.C., Abdullah, N., Tan, W.S. \& Ho, W.Y. (2005) Influence of glucanase-producing Lactobacillus strains on intestinal characteristics and feed passage rate of broiler chickens. Poultry Science 84, 734 - 741.

Soni, K.B., Lahiri, M., Chackradeo, P., Bhide, S.V. \& Kuttan R. (1997) Protective effect of food additives on aflatoxin-induced mutagenicity and hepatocarcinogenicity. Cancer letters 115, $129-133$.

Statistical Analysis System User's guide (SAS,2000) Statistics. SAS Institute Inc,cary. No 27513 U.S.A.

Viola, E.S. \& Vieira, S.L. (2007) Supplementation of organic and inorganic acidifiers in diets for broiler chickens: performance and intestinal morphology.Revista Bras. de ZootecniaBrazilian. Journal of Animal Science 36, 1097 $-1104$.

Wuthi-udomler, M., Grisanapan, W., Luanratana O. \& Caichompoo, W. (2000) Antifungal activities of plant extracts. South East Asian Journal Tropical Medical Public Health 31, Supplementary, 1, $178-182$. 
Carcass yield and intestinal morphology of male rabbits...

TABLE 1

Effects of Turmeric powder inclusion on carcass and internal organ characteristics of the Rabbits (Buck)

\begin{tabular}{|c|c|c|c|c|}
\hline \multirow{2}{*}{ Parameters } & \multicolumn{4}{|c|}{ Inclusion Level of Turmeric Powder } \\
\hline & 0 & $5 g$ & $10 \mathrm{~g}$ & $15 \mathrm{~g}$ \\
\hline \multicolumn{5}{|l|}{ Killing out } \\
\hline Live weight $(\mathrm{g})$ & $1449.00 \pm 1.15^{\mathrm{b}}$ & $1392.00 \pm 10.39^{\mathrm{b}}$ & $1579.50 \pm 44.18^{\mathrm{a}}$ & $1631.00 \pm 35.79^{\mathrm{a}}$ \\
\hline Bled weight (g) & $1414.50 \pm 4.33^{\mathrm{b}}$ & $1350.50 \pm 6.06^{\mathrm{b}}$ & $1535.50 \pm 43.01^{\mathrm{a}}$ & $1595.50 \pm 31.47^{\mathrm{a}}$ \\
\hline Singeing weight $(\mathrm{g})$ & $1370.00 \pm 5.77^{\mathrm{b}}$ & $1320.00 \pm 11.55^{\mathrm{b}}$ & $1500.00 \pm 46.19^{\mathrm{a}}$ & $1550.00 \pm 40.41^{\mathrm{a}}$ \\
\hline Eviscerated weight (g) & $987.05 \pm 5.80^{\mathrm{b}}$ & $908.90 \pm 9.41^{\mathrm{a}}$ & $1090.70 \pm 15.93^{\mathrm{a}}$ & $1146.65 \pm 50.43^{\mathrm{a}}$ \\
\hline Dressing \% & $67.91 \pm 0.57^{\mathrm{ab}}$ & $65.97 \pm 0.19^{b}$ & $69.11 \pm 0.92^{\mathrm{a}}$ & $70.23 \pm 1.55^{\mathrm{a}}$ \\
\hline \multicolumn{5}{|l|}{ Cut Parts (\%) } \\
\hline Head & $9.62 \pm 0.08^{\mathrm{a}}$ & $8.84 \pm 0.09^{\mathrm{bc}}$ & $9.45 \pm 0.41^{\mathrm{ab}}$ & $8.58 \pm 0.15^{\mathrm{c}}$ \\
\hline Fore limb & $8.92 \pm 0.01^{\mathrm{b}}$ & $9.14 \pm 0.20^{\mathrm{b}}$ & $10.42 \pm 0.11^{\mathrm{a}}$ & $10.04 \pm 0.15^{\mathrm{a}}$ \\
\hline Hind limb & $15.55 \pm 0.14^{\mathrm{b}}$ & $16.51 \pm 0.18^{\mathrm{ab}}$ & $16.82 \pm 0.68^{\mathrm{a}}$ & $17.47 \pm 0.18^{\mathrm{a}}$ \\
\hline Neck & $4.19 \pm 0.05^{\mathrm{a}}$ & $3.50 \pm 0.23^{\mathrm{b}}$ & $3.26 \pm 0.16^{\mathrm{b}}$ & $3.45 \pm 0.24^{\mathrm{b}}$ \\
\hline Tail & $0.37 \pm 0.00$ & $0.48 \pm 0.03$ & $0.42 \pm 0.00$ & $0.47 \pm 0.08$ \\
\hline Loin & $13.70 \pm 0.17^{\mathrm{a}}$ & $11.98 \pm 0.05^{\mathrm{b}}$ & $13.91 \pm 0.38^{\mathrm{a}}$ & $13.50 \pm 0.71^{\mathrm{a}}$ \\
\hline \multicolumn{5}{|l|}{ Organs (\%) } \\
\hline Liver & $2.93 \pm 0.11^{\mathrm{ab}}$ & $2.99 \pm 0.18^{\mathrm{a}}$ & $3.08 \pm 0.12^{\mathrm{a}}$ & $2.39 \pm 0.24^{\mathrm{b}}$ \\
\hline Kidney & $0.67 \pm 0.03^{\mathrm{ab}}$ & $0.51 \pm 0.02^{\mathrm{c}}$ & $0.72 \pm 0.00^{\mathrm{a}}$ & $0.61 \pm 0.02^{\mathrm{b}}$ \\
\hline Heart & $0.24 \pm 0.01$ & $0.23 \pm 0.00$ & $0.24 \pm 0.01$ & $0.24 \pm 0.01$ \\
\hline Lungs & $0.57 \pm 0.02$ & $0.58 \pm 0.02$ & $0.59 \pm 0.01$ & $0.57 \pm 0.02$ \\
\hline Spleen & $0.06 \pm 0.00$ & $0.08 \pm 0.01$ & $0.05 \pm 0.00$ & $0.06 \pm 0.00$ \\
\hline
\end{tabular}

abc: Means in the same row with different superscripts differ significantly $(\mathrm{p}<0.05)$ 
TABLE 2

Main effects of turmeric powder on intestinal morphology of the male rabbits (Buck)

\begin{tabular}{lllll}
\hline Parameters & \multicolumn{3}{c}{ Inclusion Level of Turmeric Powder } \\
\cline { 2 - 5 } & 0 & $5 \mathrm{~g}$ & $10 \mathrm{~g}$ & $15 \mathrm{~g}$ \\
\hline $\begin{array}{l}\text { Duodenum villi } \\
\text { height }(\mu \mathrm{m})\end{array}$ & $187.17 \pm 14.21$ & $234.83 \pm 21.56$ & $214.66 \pm 34.07$ & $241.83 \pm 18.95$ \\
$\begin{array}{l}\text { Duodenum crypt } \\
\text { depth }(\mu \mathrm{m})\end{array}$ & $67.67 \pm 3.01^{\mathrm{b}}$ & $73.83 \pm 4.04^{\mathrm{b}}$ & $79.33 \pm 6.38^{\mathrm{b}}$ & $111.50 \pm 14.03^{\mathrm{a}}$ \\
$\begin{array}{l}\text { Duodenum mucosal } \\
\text { thickness }(\mu \mathrm{m})\end{array}$ & $310.67 \pm 13.59$ & $324.00 \pm 18.65$ & $294.50 \pm 38.87$ & $253.33 \pm 23.43$ \\
$\begin{array}{l}\text { Jejunum villi } \\
\text { height }(\mu \mathrm{m})\end{array}$ & $338.50 \pm 45.44^{\mathrm{a}}$ & $194.33 \pm 14.73^{\mathrm{b}}$ & $136.67 \pm 20.27^{\mathrm{b}}$ & $141.67 \pm 15.30^{\mathrm{b}}$ \\
$\begin{array}{l}\text { Jejunum crypt } \\
\text { depth }(\mu \mathrm{m})\end{array}$ & $110.00 \pm 17.97^{\mathrm{a}}$ & $56.50 \pm 4.19^{\mathrm{b}}$ & $78.17 \pm 16.12^{\mathrm{ab}}$ & $103.50 \pm 12.71^{\mathrm{a}}$ \\
$\begin{array}{l}\text { Jejunum mucosal } \\
\text { thickness }(\mu \mathrm{m})\end{array}$ & $448.33 \pm 62.39^{\mathrm{a}}$ & $250.33 \pm 14.82^{\mathrm{b}}$ & $215.50 \pm 32.52^{\mathrm{b}}$ & $262.67 \pm 26.03^{\mathrm{b}}$ \\
$\begin{array}{l}\text { Ileum villi height } \\
\text { ( } \mu \mathrm{m})\end{array}$ & $200.00 \pm 60.60$ & $231.50 \pm 15.15$ & $241.50 \pm 19.10$ & $149.17 \pm 11.66$ \\
$\begin{array}{l}\text { Ileum crypt } \\
\text { depth }(\mu \mathrm{m})\end{array}$ & $98.83 \pm 23.56$ & $68.83 \pm 5.19$ & $96.33 \pm 6.83$ & $89.00 \pm 7.06$ \\
$\begin{array}{l}\text { Ileum mucosal } \\
\text { thickness }(\mu \mathrm{m})\end{array}$ & $297.67 \pm 81.85$ & $285.17 \pm 17.75$ & $354.33 \pm 22.36$ & $252.17 \pm 29.69$ \\
\hline
\end{tabular}

abc: Means in the same row with different superscripts differ significantly $(\mathrm{p}<0.05)$ 